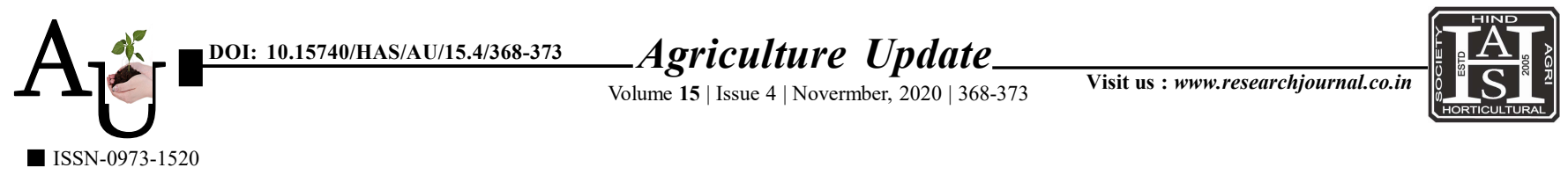

\title{
Reserźr Aвticle: Cost structure of Bt cotton in Bharuch district of South Gujarat
}

\section{J. M. Khichadiya and J. J. Makadia}

Article Chronicle: Received :

15.02.2020;

Revised:

03.10.2020;

Accepted :

$22 . .10 .2020$

KeY Words :

Bt cotton, Cost structure, Production, income

JEL Codes: D24, D57, D61 respectively. 2020: Hind Agri-Horticultural Society.
SUMMARY : This study was undertaken to determine economic analysis of production of Bt cotton in Bharuch district of South Gujarat during the year 2019-20.The study indicated that Bt cotton was a labour-intensive crop as farmer incurred highest share of 27.85 per cent and 10.95 per cent of cost of cultivation on hired labour charges and family labour charges, respectively. Overall, per hectare Cost A, Cost $\mathrm{B}_{1}$, Cost $\mathrm{B}_{2}$, Cost $\mathrm{C}_{1}$ and Cost $\mathrm{C}_{2}$ were found to be Rs. 54840, Rs. 55847, Rs. 63487, Rs. 63808 and Rs. 71448, respectively. The average annual yield of Bt cotton was 21.15 quintal per ha. Per quintal average cost of production over Cost $\mathrm{A}, \operatorname{Cost} \mathrm{B}_{1}, \operatorname{Cost} \mathrm{B}_{2}, \operatorname{Cost} \mathrm{C}_{1}$ and Cost $\mathrm{C}_{2}$ were in the tune of Rs. 2592.90, Rs. 2640.52, Rs. 3001.74, Rs. 3016.92 and Rs. 3378.16, respectively. On over all basis, per hectare farm business income, family labour income and net income were Rs. 55410.66, Rs. 46763.66 and Rs. 38802.66 , respectively. The returns per rupee on investment on Cost A, Cost $\mathrm{B}_{1}, \mathrm{Cost}_{2}, \mathrm{Cost}_{1}$ and Cost $\mathrm{C}_{2}$ were Rs. 2.01, Rs. 1.97, Rs.1.73, Rss 1.72 and Rs. 1.54 per hectare of Bt cotton cultivation,

How to cite this article : Khichadiya, J.M. and Makadia, J.J. (2020). Cost structure of Bt cotton in Bharuch district of South Gujarat. Agric. Update, 15(4): 368-373; DOI : 10.15740/HAS/AU/15.4/368-373. Copyright@
Author for correspondence :

\section{J. M. Khichadiya} Department of Agricultural Economics, N. M. College of Agriculture, Navsari Agricultural University, Navsari (Gujarat) India Email: jkhichadiya11@ gmail.com

See end of the article for authors' affiliations 